\title{
PREMEDICATION WITH MEPERIDINE AND ATROPINE DOES NOT PROLONG RECOVERY TO STREET FITNESS AFTER OUT-PATIENT SURGERY
}

\author{
A. John M. Clark and J.B. Hurtig
}

\begin{abstract}
ARSTRACT
The effect of premedication with meperidine and atropine on recovery to street fitness after out-patient surgery under general anaesthesia was assessed. The subjects of this study were 100 female patients undergoing therapeutic abortion. Two anaesthetic techniques were used; thiopentone-enflurane-nitrous oxide and thiopentone-fentanyl-nitrous oxide. The patients were comparable in age, weight, length of anaesthesia and time for recovery to street fitness after anaesthesia. The amount of thiopentone administered to the thiopentone-fentanylnitrous oxide groups was significantly greater than that administered to the thiopentoneenflurane-nitrous oxide groups. It is concluded that premedication with meperidine and atropine did not significantly prolong recovery to street fitness after out-patient surgery. Fear of prolonged recovery should not affect the decision to use premedication.
\end{abstract}

Key Words: Premedication, outpatient recovery.

Premedication of the surgical out-patient is a contentious issue. Many anaesthetists believe that premedication is unsuitable for these patients because it may prolong recovery and, thus, fitness for discharge. However, omission of premedication may not be in keeping with the best patient care. ${ }^{1}$ Absence of anxiety coupled with mild sedation has merit in anaesthetic practice ${ }^{2}$ and frequently allows for smooth induction and maintenance of anaesthesia. This study was undertaken to determine if there is a significant difference in length of recovery to street fitness after general anaesthesia in unpremedicated surgical out-patients and those premedicated with meperidine and atropine.

\section{Methods ANd MAterials}

This study was approved by the Committee on Research of the Ottawa Civic Hospital. One hundred ASA Class I female patients scheduled to undergo therapeutic abortion under general anaesthesia were studied. Each patient gave written informed consent and all patients fasted for at least eight hours before operation.

The patients were divided into two groups of fifty each. Group I received an anaesthetic consisting of induction with thiopentone 2.5 per cent intravenously until loss of eyelid reflex, followed

A. John M. Clark, M.D., Chief Resident; J.B. Hurtig, M.D., F.R.C.P.(C), Assistant Professor; Department of Anaesthesia, Ottawa Civic Hospital, University of Ottawa, 1053 Carling Avenue, Ottawa, Ontario, KIY 4E9. by 70 per cent nitrous oxide and 30 per cent oxygen with 2-4 per cent enflurane to maintain adequate depth of anaesthesia. Group II received fentanyl $1.5 \mu \mathrm{g} \cdot \mathrm{kg}^{-1}$ intravenously, to a maximum of $100 \mu \mathrm{g}$, two minutes before induction with thiopentone 2.5 per cent intravenously until loss of eyelid reflex, followed by 70 per cent nitrous oxide and 30 per cent oxygen with supplemental thiopentone as necessary to maintain adequate depth of anaesthesia.

Half the patients in each group were randomly premedicated 30 to 60 minutes preoperatively with intramuscular meperidine $1.0 \mathrm{mg} \cdot \mathrm{kg}^{-1}$ to a maximum of $75 \mathrm{mg}$ and atropine $0.01 \mathrm{mg} \cdot \mathrm{kg}^{-1}$ to a maximum of $0.4 \mathrm{mg}$. All patients were monitored with a continuous electrocardiogram and a blood pressure cuff, and received $500 \mathrm{ml}$ of lactated Ringer's solution with 20 units of synthetic oxytocin added.

All patients recovered in a similar fashion. Vital signs were monitored until patients were fully awake. This was followed by gradual ambulation. This consisted of sitting with the legs dangling over the side of the bed, followed by standing and then walking. They then had to demonstrate the ability to retain fluids and to void. At each level stable vital signs had to be maintained. When these criteria had been met the patients were considered fit for discharge. In addition each patient was requested to complete a Treiger Modified Bender-Gestalt Dot Test, which required the patient to join a series of dots. ${ }^{3}$ This was done preoperatively before any drugs had been administered and again at the time 
TABLE I

Patient Data (Mean \pm I S.D.)

\begin{tabular}{lccccc}
\hline \hline & \multicolumn{2}{c}{$\begin{array}{c}\text { Group I } \\
\text { (enflurane) }\end{array}$} & & \multicolumn{2}{c}{$\begin{array}{c}\text { Group II } \\
\text { (fentanyl-thiopentone) }\end{array}$} \\
\cline { 2 - 3 } & Premed. & No Premed. & & Premed. & No Premed. \\
\hline Number of patients & 25 & 25 & & 25 & 25 \\
Age (Yrs) & $23 \pm 5$ & $22 \pm 3$ & & $23 \pm 6$ & $23 \pm 6$ \\
Weight (kg) & $56 \pm 6$ & $59 \pm 13$ & & $57 \pm 8$ & $55 \pm 7$ \\
Thiopentone* Dose (mg $\cdot \mathrm{kg}^{-1}$ ) & $6.1 \pm 1.1$ & $5.7 \pm 1.3$ & & $6.7 \pm 1.3$ & $7.0 \pm 1.3$ \\
Anaesthesia Time (min) & $11.6 \pm 3.9$ & $11.7 \pm 3.6$ & & $11.4 \pm 4.0$ & $11.7 \pm 4.0$ \\
Recovery Time (min) & $187 \pm 43$ & $176 \pm 36$ & & $193 \pm 29$ & $179 \pm 37$ \\
\hline
\end{tabular}

*Group I vs Group II p $<0.01$.

TABLE II

Number of Patients with Side Effects Pre- And Post-Operatively

\begin{tabular}{|c|c|c|c|c|c|c|c|c|}
\hline & \multicolumn{4}{|c|}{$\begin{array}{c}\text { Group I } \\
\text { (enflurane) }\end{array}$} & \multicolumn{4}{|c|}{$\begin{array}{c}\text { Group II } \\
\text { (fentanyl-thiopentone) }\end{array}$} \\
\hline & \multicolumn{2}{|c|}{ Premed. } & \multicolumn{2}{|c|}{ No Premed. } & \multicolumn{2}{|c|}{ Premed. } & \multicolumn{2}{|c|}{ No Premed. } \\
\hline & Preop. & Postop. & Preop. & Postop. & Preop. & Postop. & Preop. & Postop. \\
\hline Number of patients & \multicolumn{2}{|c|}{25} & \multicolumn{2}{|c|}{25} & \multicolumn{2}{|c|}{25} & \multicolumn{2}{|c|}{25} \\
\hline Nausea and/or Vomiting & 1 & 2 & - & 3 & 2 & 2 & - & 3 \\
\hline Lightheaded, Dizziness & - & 2 & - & - & - & 1 & - & - \\
\hline Other & - & 1 & - & 1 & - & - & - & - \\
\hline
\end{tabular}

of discharge to assess sensory and motor performance.

The anaesthetist and the personnel caring for the patients in the operating and recovery rooms were unaware whether the patients had been premedicated. The data were analyzed by analysis of variance.

\section{Results}

The characteristics of the patients in the study, the dose of thiopentone, the anaesthetic and recovery times are shown in Table $\mathbf{I}$.

There was no significant difference among the groups with respect to age, weight, or length of anaesthesia. Although recovery time was slightly longer in the premedicated patients, this was not statistically significant. The larger dose of thiopentone in the fentanyl-thiopentone groups was statistically significant when compared to that administered to the enflurane groups $(P<0.01)$; however premedication did not significantly affect the dosage of thiopentone in either the enflurane or fentanyl-thiopentone groups.

The incidence of side effects is shown in Table II. There were no preoperative side effects in the unpremedicated patients, while three of the $\mathbf{5 0}$ premedicated patients had side effects in this period. Postoperatively 15 of the 100 patients experienced side effects. Those patients receiving enflurane had a higher incidence of side effects than those receiving fentanyl and thiopentone. Premedication did not appear to have an effect, although the numbers are too small for statistical analysis.

Comparison of the Trieger Modified BenderGestalt Dot Test completed preoperatively and at time of discharge indicated recovery of sensory and motor function in all patients tested.

\section{Discussion}

Any drug which a patient receives in the perioperative period may have an effect on the course of recovery after general anaesthesia. Several drugs which can be used as premedication have been shown to prolong the recovery time. Diazepam can be unpredictable; it has a biphasic half-life, long action and can cause ataxia and dizziness. ${ }^{2,4-6}$ Droperidol is long acting and can cause drowsiness, dystonia, anxiety and postural hypotension. ${ }^{2}$ Hyoscine may produce disorientation and agitation on emergence from anaesthesia. ${ }^{2}$ Some narcotics are also long- 
acting and may cause respiratory depression, nausea, vomiting and dysphoria. ${ }^{1,2}$

However premedication is sometimes required in the surgical outpatient to provide relief from anxiety and apprehension, to produce a mildly sedated state and a smoother, uncomplicated induction. Patients who are undergoing therapeutic abortion tend to be anxious and apprehensive. We selected meperidine and atropine because this is a commonly used premedicant combination. Meperidine has been shown to provide some relief of apprehension and to create drowsiness ${ }^{7}$ and to have a shorter duration of action than other commonly used narcotics such as morphine. ${ }^{8}$ In this study the incidence of side effects such as nausea, vomiting or dizziness after premedication but before induction of anaesthesia was minimal.

Short inhalation and narcotic-nitrous oxide anaesthetics have been shown to differ minimally in their effects on length of recovery to street fitness. ${ }^{9}$ Enflurane may be a more suitable agent than halothane for surgical outpatients since the initial uptake of enflurance is slightly faster than that of halothane and, because of its lower affinity for lipids, its uptake by body fat is less and it is eliminated from the body slightly faster than halothane. ${ }^{10}$ Enflurane has also recently been shown to cause less malaise and mental impairment after anaesthesia than halothane. "Uterine relaxation has been found to be similar with enflurane and halothane and, consequently, was not a consideration in the choice of agent. ${ }^{12}$

Fentanyl has a short duration of action when used as in this study. ${ }^{2,8}$ It has also been shown to contribute to a smoother anaesthetic, reduction in total dose of thiopentone necessary to maintain an adequate depth of anaesthesia, reduction of postoperative pain and negligible effect on time to walking or demonstration of a negative Romberg test when added to thiopentone nitrous oxide-oxygen anaesthesia. ${ }^{13}$ Rapid recovery after thiopentone is a consequence of its rapid redistribution. ${ }^{8}$ The higher dose of thiopentone in the fentanyl-thiopentone groups was not surprising and was the result of need to supplement anaesthesia with thiopentone during the operative procedure. However, the predictably higher tissue concentration of thiopentone did not prolong recovery as measured by this study.

The premedicated patients in both anaesthetic groups had slightly longer recovery time to fitness for discharge than the unpremedicated patients; however the difference was not significant clinically or statistically. It is suggested that the need for premedication be considered in light of clinical circumstances and that fear of prolonged recovery from anaesthesia should not affect the decision.

\section{ACKNOWLEDGEMENTS}

We are indebted to Mrs. Lynne McHardy for the preparation of the manuscript and R.C. Nair, N. Stat., Ph.D., for assistance with the statistical analysis.

\section{REFERENCES}

1. Coвb, L.M. \& Stephen, C.R. Role of premedication in outpatient anaesthesia. Contemp. Anesth. Pract. I: 31-42 (1978).

2. Schmidt, K.F., Garfield, J.M. \& Korten, K. The pharmacology of agents used in outpatient anaesthesia. Int. Anes. Clinics, Vol. 14 (2), 15-49 (1976).

3. Newman, M.G., Treiger, D.M.D. \& Miller, J.C. Measuring recovery from anaesthesia - a simple test. Anesth. Analg. (Cleve), 48: 1, 136-140 (1969).

4. Epstein, B.S. Outpatient anesthesia. A.S.A. Refresher Courses in Anesthesiology. Vol. 2, Ch. 7, 81 (1974).

5. ReEd, W.A., Couch, B.L. \& Ford, J.L. Anesthesia and operations on outpatients. Public Health Aspects of Critical Care Medicine and Anesthesiology. 10:3, 336 (1974).

6. BAIRD, E.S. \& HAILEY, D.M. Delayed recovery from a sedative: correlation of plasma levels of diazepam and clinical effects after oral and intravenous administration. $\mathrm{Br}$. J. A naesth. 44: 803-808 (1972).

7. Dundee, J.W., Moore, J. \& Clarke, S.J. Studies of drugs given before anaesthesia $V$ : pethidine $100 \mathrm{mg}$ alone and with atropine and hyoscine. $\mathrm{Br} . \mathrm{J}$. Anaesth. 36: 703-710 (1964).

8. Goodman, L.S. \& Gillman, A. The pharmacological basis of therapeutics. 5th Ed. (New York), MacMillan Publishing Inc. (1975).

9. Enright, A.C. \& Pace-Florida, A. Recovery from anaesthesia in outpatients: a comparison of narcotic and inhalational techniques. Canad. Anaesth. Soc. J. 24: 618-622 (1977).

10. Torri, G., Damia, G. Fabiani, M.L. et al Uptake and elimination of enflurane in man, a comparative study between enflurane and halothane. Br. J. Anaesth. 44: 789-794 (1972).

11. Storms, L.H., Stark, A.H., Calverley, R.K. \& SMiTh, N.T. Psychological functioning after halothane or enflurane anesthesia. Anesth. Analg. (Cleve) 59: 245-249 (1980).

12. Munson, E.S. \& Embro, B.S. Enflurane, isoflur ane and halothane and isolated human uterine muscle. Anaesthesia 46: 11-14 (1977).

13. Erstein, B.S., Levy, M.L., Thein, M.H. \& COAKLEY, C.S. Evaluation of fentanyl as an adjunct to thiopentalnitrous oxide-oxygen anesthesia for short surgical procedures. Anesthesiol. Rev. 2: 24-29 (1975). 


\section{RÉSUMÉ}

L'effet d'une prémedication à la mépéridine avec atropine sur le temps nécessaire à l'atteinte de l'aptitude à la rue chez des malades ambulatoires faisait l'objet de cette recherche. Cent patientes soumises à un avortement thérapeutique ont été prémédiquées ou non, dans le cadre de cette étude à double -insu. La moitié des patientes on été anesthésiées au thiopental suivi d'enflurane et de protoxyde d'azote alors que l'autre groupe de malades recevait du protoxyde d'azote, du fentanyl et du thiopental.

Les malades des deux groupes étaient comparables aux points de vue de l'âge, du poids et de la durée de l'anesthésie; l'aptitude à la rue était égalcment atteinte en un temps semblable chez les patientes des deux groupes. Les doses de barbituriques requises chez les patientes recevant le protoxyde d'azote avec fentanyl étaient significativement plus élevées que chez celles anesthésiées au mélange enflurane-protoxyde. La pré-médication à la mépéridineatropine n'a pas prolongé de façon significative le temps nécessaire à l'atteinte de l'aptitude à la rue après chirurgie ambulatoire. La crainte d'une récupération prolongée ne doit donc pas influencer la décision d'utiliser ou non une prémédication chez ces malades. 